\title{
STUDY ON THE EFFICIENCY OF CASH WAQF MANAGEMENT IN MALAYSIA
}

\author{
Siti Razifah Khamis ${ }^{1}$ \\ Marhanum Che Mohd Salleh ${ }^{2}$
}

\begin{abstract}
The role of Waqf is synonym with the purpose of developing the economics as well as social well-being by means of a charity-based system. Revitalization of cash Waqf gives advantage to Muslims countries to further enhance this charity system. However, the efficiency of cash Waqf management is still questionable due to several internal management issues. This research is conducted to three objectives; to explore current practices of Waqf institutions in managing cash Waqf concerning human resource, documentation and reporting aspect; to investigate challenges faced by Waqf institutions in managing cash Waqf in terms of human resource, documentation and reporting aspects; and to suggest a few ways that can enhance the efficiency of cash Waqf management focusing in the three aspects. To achieve these objectives, qualitative methodology has been adopted where the data of this research was collected through semi-structured interview and review of past literatures as well as relevant documents. The finding of the research shows that majority of Waqf institutions have made efforts in promoting cash Waqf based on its regulation, financial sources, collaboration, duration of cash Waqf implementation and its strategic planning. However, the current practices of human resource, documentation and reporting are not suitable with the current pace of evolution to fully realize the benefit of cash Waqf. This research revealed the loopholes in the management of cash Waqfand suggested several ways for improvement as a reference for Waqf institutions in order to improve their cash Waqf implementation. It is a significant endeavor for Waqf institutions in Malaysia to develop knowledge on cash Waqf management as well as provoking speedy development progress of cash Waqf implementation in Malaysia.
\end{abstract}

Keywords: Efficiency, Cash Waqf, Human Resources, Reporting, Documentation, Malaysia JEL Classification: L3, Z12, M1

Received : September 5, 2017

Revised : August 15, 2018

Accepted : August 16, 2018

1. Department of Finance, Faculty of Economics \& Management Sciences, International Islamic University Malaysia, Email: razifahkhamis@gmail.com.

2. Department of Finance, Faculty of Economics \& Management Sciences, International Islamic University Malaysia, Email: marhanum@iium.edu.my. 


\section{INTRODUCTION}

The definition of Waqf is based on the Arabic word Waqafa which means 'causing a thing to stop and standstill'. It also means 'detention', 'holding', or 'keeping' (Chowdhury, Ghazali, \& Ibrahim, 2011). This prevents the asset from being subject of inheritance, sale, gift, pawn, leased and so on (Al Arif, 2010). Traditionally, the Waqf mechanism only allowed the involvement of immovable property or real estate such as building and land. Unfortunately, it caused the management problems of unproductive Waqf property and insufficient Waqf fund, as the saying goes 'Asset Rich Cash Poor' scenario (Ismail, Muda, \& Hanafiah, 2014). In Malaysia, these problems become the primary topic of discussions by the industry practitioners as well as the academicians. Fortunately, the permission to use movable property as a Waqf asset, specifically in kind of cash, has been endorsed by Malaysian Fatwa Council in 2007 which has slightly resolved these problems (Ibrahim \& Ibrahim, 2013; Ibrahim, Amir, \& Masron, 2013a; Medias, 2010; Hosseini, Salari, \& Abadi, 2014; Saifuddin, Kayadibi, Polat, Fidan, \& Kayadibi 2014).

Cash Waqf is pooled as Waqf asset and it must be managed wisely until it grows and generates income for social welfare (Saad \& Anuar, 2010; Tohirin \& Hudayati, 2011; Saifuddin et al., 2014). Basically, the Waqf institutions are responsible in managing the Waqf asset including the cash Waqf. The proper cash Waqf management involves three main phases which consists of Waqf fund collection, Waqf fund investment and Waqf fund (profit) disbursement (Manat, 2007; Mohsin, 2013; Tohirin \& Hudayati, 2011). However, there are several impediments faced by Waqf institutions in Malaysia that cause the cash Waqf management to be inefficient. It is basically due to internal constraints which are lacking in qualified human resource, transparent reporting and systematic documentation (Ibrahim \& Ibrahim, 2013; Manat, 2007; Masruki \& Shafii, 2013; Shakrani, Noor, \& Ali, 2003; Yaacob, Petra, Sumardi, \& Nahar, 2012). Besides that, the external constraint, including the absent of standardized Waqf enactments, has also affected the efficiency of cash Waqf management (Shakrani et al., 2003; Ibrahim \& Ibrahim, 2013).

Thorough research is urgently needed to investigate the current management issues of cash Waqf in order to enhance the efficiency of cash Waqf management in Malaysia. However, this research will not capture the external constraints, as it will require more time and in-depth knowledge in legal as well as Islamic jurisprudence.

The main objective of this research is to study the current practices and its challenges of cash Waqf management in selected Waqf institutions in Malaysia. The specific objectives of the research are:

i. To explore the current practices of the Waqf institutions in managing cash Waqf concerning human resource, documentation and reporting aspect.

ii. To investigate the challenges faced by Waqf institutions in managing cash Waqf concerning human resource, documentation and reporting aspect.

iii. To suggest a few ways that can enhance the efficiency of cash Waqf management mainly in terms of human resource, documentation and reporting. 


\section{RELATED LITERATURE}

\subsection{What is Cash Waqf}

Cash Waqf is an amount of money donated from one's possessions for social welfare or any special purposes (Khademolhoseini, 2008; Mohsin, 2013). Similarly, it is the cash invested in profitable economic sectors for certain percentages for social benefit (Hilmi, 2012b). In other words, cash Waqf means cash endowed to the authorized Waqf trustee where the principal is preserved for the benefit of the beneficiaries (JAWHAR, 2009). Cash Waqf is also known to be one of the financial methods designed by the Muslim jurist for the development of Waqf properties around the world (Iman \& Mohammad, 2014).

\subsection{Regulation of Cash Waqf in Malaysia}

The legality of cash Waqf in Malaysia refers to the List II, State List, Schedule Ninth, Federal Constitution (JAWHAR, 2009). It stated that the authority of Waqf, which also includes cash Waqf, is under the state jurisdiction as stated below:

... Islamic law and personal and family law of persons professing the religion of Islam, including the Islamic law relating to succession, testate and intestate, betrothal, marriage, divorce, dower, maintenance, adoption, legitimacy, guardianship, gifts, partitions and non-charitable trusts; Wakafs and the definition and regulation of charitable and religious trusts, the appointment of trustees and the incorporation of persons in respect of Islamic religious and charitable endowments, institutions, trusts, charities and charitable institutions operating wholly within the State;...(Federal Constitution: Schedule Ninth, State List, List II)

Therefore, all activities related to cash Waqf shall be under the State Islamic Religious Council (SIRC) who acts as the sole trustee. However, the existing law does not prohibit any other bodies or institutions to manage cash Waqf. This can be done through SIRC's consent.

Currently, all management of Waqf, including the management of cash Waqf, in each state of Malaysia is based on the statute of their SIRC except in Selangor, Melaka and Negeri Sembilan. Selangor has introduced the Wakaf (State of Selangor) Enactment 1999 on $30^{\text {th }}$ December 1999 and came into effect on $1^{\text {st }}$ July 2004. Melaka's Wakaf (State of Malacca) Enactment 2005 was introduced on $28^{\text {th }}$ April 2005 and implemented since $1^{\text {st }}$ August 2005. Negeri Sembilan also introduced the Wakaf (Negeri Sembilan) Enactment 2005 on $2^{\text {nd }}$ February 2005 but it has not yet been enforced.

\subsection{Development of Cash Waqf Malaysia}

Malaysia has taken the initiative to intensify the benefits of cash Waqf by introducing Department of Awqaf, Zakat and Hajj (JAWHAR) with the objective to standardize the management of cash Waqf. JAWHAR was founded on $27^{\text {th }}$ March 2004 by former Prime Minister of Malaysia, YAB Tun Abdullah Ahmad Badawi. The official launch was completed by Dato' Seri Abdullah bin Md Zin, a former Minister in the Prime Minister's Department, who was responsible for Islamic affairs on $8^{\text {th }}$ October 2004 held at Putrajaya International Convention Centre (PICC). 
In view of that, there are several cash Waqf initiatives advised by JAWHAR to be organized by each SIRC. First, the SIRC shall open a bank account in any Islamic banking institutions to be cash Waqf trust account. Second, via salary deduction, where SIRC shall assist the public and private servants to participate by getting the Salary Deduction Code from Accountant General's Department of Malaysia, State Treasurer and Manpower Department approval for the public, civil and private servants respectively. Third, SIRC shall acquire permission for tax exemption for those who contributing in cash Waqf from the Inland Revenue Board of Malaysia or Ministry of Finance. Fourth, SIRCs are encouraged to collaborate with any Islamic financial institutions to enhance public participation through banking facilities such as internet banking, standing instruction and cash deposit machines. At one fell swoop, the collaboration may further support the marketing of cash Waqf to other account holders. Fifth, SIRCs shall give a written authorization to the officers, staff or any person in charge of collecting and receiving the cash Waqf as a means to prevent fraud. Sixth, SIRCs also need to prepare official documents in the cash Waqf implementation that includes Cash Waqf Receipt, Participation form, Monthly Salary Deduction Approval form, Cash Waqf Collection Statement and Cash Waqf certificate.

\subsection{Cash Waqf Management}

Iman and Mohammad (2014) stated that "Waqf management requires three fundamental resources: people, money, and property or asset". The Waqfinstitutions need people with proper educational background who have professional training and certification programs. Money is also needed with the right amount at the right time. The property or asset in this case can be described as the tangible as well as the intangible assets of Waqf institutions.

Cash Waqf needs proper management to ensure its effectiveness and efficiency. Kahf (1999) stressed several requirements that must be realized for the Waqf industry to be the main role in economic development. One significant requirement that is worth to be mentioned in this research is the complete revision of the Waqf management, especially the investments in order to enhance efficiency and minimize corruption of Nadzir. The same author also highlighted that Waqf institutions shall provide a new style of management that will uphold the concept of amanah (trustworthy).

The cash Waqf management system in Indonesia that has been proposed by Masyita et al. (2005) comprises of six interrelated components. These includes Waqif (rich), cash Waqf fund, investment portfolios, investment profits, available funds for the poverty programs and the Mawquf a'laihi (poor). Since Waqf institutions serve as the third sector of non-profit organizations, Waqf institutions should be independent, committed, specialized and altruist in order to be more effective and efficient in socio-economic development (Iman \& Mohammad, 2014).

\subsubsection{Human resource}

Nadzir in a Waqf institution, particularly in cash Waqf management, is responsible for three main duties that are the cash Waqf accumulation cash Waqf investment 
and cash Waqf distribution. This is in line with a study by Tohirin and Hudayati (2011) where the authors proposed that Waqf institutions should obtain three sections, which consist of funds procurement section, funds utilization section and income distribution section.

Waqf institutions require highly competent personnel not only in management but also in Islamic finance and investment. Therefore, the staff must also uphold the concept of transparency, productivity, and integrity (Masyita \& Febrian, 2004). In addition, the Waqf institutions should be administered by professional knowledge and skills to keep the assets highly productive and income generating (Iman \& Mohammad, 2014).

\subsubsection{Documentation system}

According to Toraman et al. (2007), the documentation of cash Waqf management during the $18^{\text {th }}$ century require the details of the Waqf. It consisted of the name of the Waqf and purpose of the establishment; details of the amount involved, which consisted of the original amount, additional amount and the return; and details of the Mawquf'alaihi, which consisted of names, amount borrowed, address, religious domination and gender.

In Malaysia, the process flow suggested by JAWHAR in the documentation of cash Waqf collection is as follows. First, the SIRCs need to make sure the participants or Waqif completed the registration and approval form. Second, the SIRCs have to submit the forms to the respective Accountant General's Department of Malaysia. Once completed, the SIRC shall prepare periodic receipts upon the issuance of Cash Waqf Scheme check by the Accountant General. Then the SIRCs need to prepare the collection statement to deposit the check to their cash Waqf accounts. Thus, to ensure transparency of cash Waqf management, Waqf institutions should have comprehensive documentation guidelines and rules (Tohirin \& Hudayati, 2011).

\subsubsection{Reporting system}

Mohsin (2013) stressed that the investment activities shall be disclosed annually and the information shall be made available to the persons involved. JAWHAR also recommended each SIRC to report the exchange of cash Waqf into immovable assets, the investment of cash Waqf fund and the financial statement periodically. However, it is observed that only three SIRCs managed to disclose their annual reports to the public: The Islamic Religious Council of Wilayah Persekutuan (MAIWP), Selangor (MAIS) and Perak (MAIPk).

To sum up, the current research aims to address the human resource management, documentation system and reporting system in concerned and targeted Waqf institutions in response to the lack of public trust towards the Waqf institution in Malaysia. This is because previous research found that many people did not trust the management and the investment of cash Waqf by the existing government institutions as cash Waqf may eventually involve a large amount of funds that require a highly capable institution to ensure trustworthiness (Masyita et al., 2005). The current research is needed to address these issues as a revelation to the related institutions. 


\subsection{Challenges of Cash Waqf Management}

Several issues must be tackled in order to ensure the effectiveness of cash Waqf management. However, to the best of the author's knowledge, there are only a few studies discussing the challenges in cash Waqf management. Therefore, the current author identified the problem in general term as encountered in the Waqf institutions based on previous studies. The challenges are divided into two divisions, which consist of internal and external factors.

\subsubsection{Internal}

The internal factors consist of human capital, management strategies and technology utilization. In general perspective, the human capital who are involved in Waqf management and development in most SIRC are not professionally trained (Iman \& Mohammad, 2014). JAWHAR also mentioned the same issue of insufficient certified and experienced accounting officers in the Waqf area, which caused delay of Waqf financial reporting. The Nadzir is responsible to maintain the principal amount of the cash Waqf (Masyita \& Febrian, 2004). Since cash Waqf involves money, it may encounter diminishing of values as money depends on inflation rates and currency exchange rates (Tohirin \& Hudayati, 2011). For that reason, the Nadzir should be a highly capable institution in aspect of Islamic financial management. Unqualified Mutawali or Waqf manager is the most critical challenge in managing the Waqf as has been discussed in a number of studies (Nurrachmi, 2012). This is because; unqualified Nadzir may induce arrangements with nonShari'ah compliant activities or ribawi (interest-based) investment unintentionally (Tohirin \& Hudayati, 2011).

In Indonesia, a study on three Waqf institutions regarding issues on cash Waqf management surround the management strategies such as cash Waqf collection, disbursement, principal preservation, risk management and reporting in order to discharge the Waqfinstitution obligations (Fanani, 2011). Similarly, Rozalinda (2012) emphasized that cash Waqf need proper risk management to sustain its growth to be as good as the Islamic banking performance. This is because unproductive endowment is the result of ineffective management (Rozalinda, 2012). In other words, the Waqf institutions must generate strategies and critically evaluate all strategies to implement the best plan of action in order to gain the best results. Moreover, lack of marketing conducted by SIRCs also signifies poor management by the Waqf institutions. Limited programs scope, awareness campaign as well as education on Waqf concept, specifically cash Waqf, are also the challenges towards the development of cash Waqf in Malaysia (Htay et al., 2012). Lack of monetary resource is one of the consequences of poor education of Waqf and cash Waqf concept to the public.

As the Waqf institution is a non-profit organization, the utilization of advance technology such as server, program and software is at a minimal level as compared to profit-making organizations such as financial institutions. However, Waqf institutions also should use the same or at least equivalent technology as financial institutions because Waqf institution also deals with money. Iman and Mohammad (2014) expressed that the SIRC does not have a comprehensive reliable information system to aid in development planning. This leads to error, incomplete, inconsistent, duplicative and missing data or records. 


\subsubsection{External}

The external factor is explained in terms of the absence of standardized law. Absence of standardized Waqf law inhibits the efficient management of cash Waqf in Malaysia (Htay et al., 2012; Shahimi et al., 2013). This is due to the reason that the laws related to Waqf administration in most of the state enactments are not comprehensive (Hanefah et al., 2009). In addition, Hanefah et al. (2009) also discussed other legal issues concerning the nature of Waqf property, the status of Waqf asset, the power of Mufti, the judgment of Shari'ah and civil courts regarding Waqf assets and many other legal issues. Apart from that, JAWHAR also mentioned that the absence of Waqf guidelines, which explains the reporting requirements in detail, is one issue in cash Waqf management. The lack of financial standard in monetary reporting of cash Waqf also questioned the transparency of its implementation.

\subsection{Previous and Current Studies on Cash Waqf}

There are several researches specifically on cash Waqf. In this research, 21 literatures consisting of books, article journals, theses and conference papers are being discussed on several topics of concern. The first area of study concerns the management practices, which discusses on the legal, accounting and operation perspectives. Hilmi (2012a) discussed the management issues from a legal perspective and stated that the management practices are not being executed as expected. Similarly, Toraman et al. (2007) stated that cash Waqf management practices should take example of the accounting practices during the Ottoman Empire. Chowdhury et al. (2011), in context of Malaysia, addressed the cash Waqf management issues and proposed several modern applications of the concept such as cash Waqf bank, Waqf Takaful, microfinance, Small and Medium Enterprise (SME) loan and others which could enhance the public's involvement. Meanwhile, Tohirin and Hudayati (2011) also touched on the accounting practices of the cash Waqf model. Another study by Ismail et al. (2014) reviewed the challenges and prospect with the aim to ensure the efficient management of cash Waqf. Correspondingly, Rozalinda (2012) critically argue the effectiveness of risk management pertaining cash Waqf investment.

The second area of study concerns the financing and funding through the cash Waqf medium. Masyita and Febrian (2004) discussed the use of this concept as micro financing in order to assist the microenterprise and reduce poverty. In the same way, Saad \& Anuar (2010) debated the same theme and solved the shortcomings of the current practices by proposing Islamic microfinance. Correspondingly, Marzuki et al. (2012) also examined the use of cash Waqf micro financing as poverty alleviation by formulation of government policies. Similarly, Amuda and Embi (2013) also studied the same area of concern but within the context of Organization of Islamic Cooperation (OIC) countries. Meanwhile, Mohsin (2013) researched the potential of cash Waqf as a global financial aid to fulfill global needs such as education, health, social care and commercial activities, basic infrastructures, as well as employment.

The third area of study concerns the development of cash Waqf. This is as studied by Sudirman (2004) on cash Waqf model development of TWI (Tabung 
Wakaf Indonesia). This includes the development of a computer program in enhancing the collection of cash Waqf (Masyita et al., 2005). Besides, Ibrahim et al. (2013b) justified the model and management structure of cash Waqf while exploring the development of cash Waqf in northern Malaysia, particularly in the Penang state. Relatedly, Amuda et al. (2014) studied the development of cash Waqf for agriculture. Another research by Saifuddin et al. (2014), concerned about the education of cash Waqf to the public with the intention to maximize the potential of this concept.

The fourth area of study is concerning the legality of cash Waqf. In general, most of the study touches on the legality of cash Waqf practices. Yet, Hayani (2007) has contributed a remarkable effort to the literature by critically explaining the legality of cash Waqf based on Muslims scholars' perspectives, specifically the Hanafi's and Shafi'i's school of thought. Other areas of concern in cash Waqf are the determinants of cash Waqf giving (Htay et al., 2012) and the distribution area of cash Waqf (Pitchay et al., 2014) which both indirectly contribute to the development of cash Waqf. Therefore, the current research fulfills the gaps of limitation of literature in the area of cash Waqf management.

\section{METHODOLOGY}

This research adopts qualitative research method to investigate cash Waqf management practices for the intended Waqf institutions. This is due to the fact that, the qualitative research contributes to vivid and insightful results (Burns \& Bush, 2010). Furthermore, this method has a dynamic character of the interview process which engages respondents more actively and enables the researcher to reach beyond initial responses and grounds (Burns \& Bush, 2010).

This research is basically exploratory in nature with the objectives to investigate cash Waqf management practices as well as the challenges of the current practices of cash Waqf in Malaysia. This research involved two stages of data collection; exploratory (information gathering) and Semi-Structured Interview. The purpose of conducting the interview session is to identify the current practice of cash Waqf management as well as the challenges and problems that arise at the Waqf institutions in Malaysia. Indeed, interview is a useful and efficient way to collect information that cannot be obtained in published form (Eriksson \& Kovalainen, 2008). Therefore, semi-structured interview is suitable to be adopted in this research to gather information from operational officers and staff of the selected Waqf institutions. In that way, it probes the Waqf institutions to provide rich information on cash Waqf management.

\section{FINDING}

\subsection{Regulation of Waqf and cash Waqf in Malaysia}

This section explores in detail the enactments adopted by the Waqf institutions in Malaysia to evaluate their attentiveness towards the implementation of Waqf and cash Waqf. The method used is exploratory research through websites of http:// www.esyariah.gov.my and http://www.jawhar.gov.my. The assumption is if the Waqf institution has specific Waqf enactment, that Waqf institution is more attentive towards the implementation of Waqf and cash Waqf. 
Previous research by Kader (2015) stated that there are four Waqf laws available in Malaysia, which is Johor Wakaf Rules 1983, Selangor Wakaf Enactment 1999, Negeri Sembilan Wakaf Enactment 2005, and Melaka Wakaf Enactment 2005 for Johor, Selangor, Negeri Sembilan and Melaka respectively. In other words, these states are keen in promoting Waqf as well as cash Waqf.

Based on the findings from the exploratory research through the websites and portals of each Waqf institutions in Malaysia, the research found that only three Waqf institutions have specific Waqf enactment. This consists of Selangor, Melaka and Negeri Sembilan ${ }^{3}$. Therefore, it can be concluded that these three states are currently active in promoting Waqf as well as cash Waqf as they have specific enactments that rule the management of Waqf and cash Waqf. Accordingly, based on Table 1, Region A, B and E does not have any specific enactments that rule the management of Waqf. Thus, for Waqf management, the state refers to the same enactment in force, which regulates the Islamic affairs of the particular state. Conversely, some states in Region B and C have specific enactment that rule the management of Waqf. In other words, Region B and C are actively promoting the Waqf followed by cash Waqf.

Table 1.

List of SIRCs or Baitulmal Institutions based on Regions in Malaysia with the Enactment Adopted and the Corresponding Codes

\begin{tabular}{|c|c|c|c|c|c|}
\hline No. & State & $\begin{array}{l}\text { Islamic State } \\
\text { Council }^{4}\end{array}$ & $\begin{array}{l}\text { Enactment adopted for } \\
\text { Waqf } \text { Management } t^{5}\end{array}$ & Region & $\begin{array}{l}\text { Region } \\
\text { Codes }\end{array}$ \\
\hline 1. & Perlis & $\begin{array}{l}\text { Majlis Agama } \\
\text { Islam Perlis }\end{array}$ & $\begin{array}{l}\text { Administration of the } \\
\text { Religion of Islam Enactment } \\
2006 \text { (En. 4/2006) }\end{array}$ & Northern & A \\
\hline 2. & Kedah & $\begin{array}{l}\text { Majlis Agama } \\
\text { Islam Kedah } \\
\text { Darul Aman }\end{array}$ & $\begin{array}{l}\text { Administration of Islamic } \\
\text { Law (Kedah Darul Aman) } \\
\text { Enactment } 2008 \text { (En. 5/08 / } \\
\text { En.9) }\end{array}$ & & \\
\hline 3. & Penang & $\begin{array}{l}\text { Majlis Agama } \\
\text { Islam Pulau } \\
\text { Pinang } \\
\text { (MAIPP) }\end{array}$ & $\begin{array}{l}\text { Administration of The } \\
\text { Religion of Islam (State Of } \\
\text { Penang) Enactment } 2004 \text { (En. } \\
\text { 2/2004) }\end{array}$ & & \\
\hline 4. & Perak & $\begin{array}{l}\text { Majlis Agama } \\
\text { Islam dan } \\
\text { Adat Melayu } \\
\text { Perak (MAIPk) }\end{array}$ & $\begin{array}{l}\text { Administration of The } \\
\text { Religion of Islam (Perak) } \\
\text { Enactment } 2004 \text { (En. 4/2004) }\end{array}$ & & \\
\hline 5. & Kelantan & $\begin{array}{l}\text { Majlis Agama } \\
\text { Islam dan } \\
\text { Adat Istiadat } \\
\text { Melayu } \\
\text { Kelantan } \\
\text { (MAIK) }\end{array}$ & $\begin{array}{l}\text { Council of The Religion of } \\
\text { Islam and Malay Custom, } \\
\text { Kelantan Enactment } 1994 \\
\text { (En. 4/1994) }\end{array}$ & East Coast & B \\
\hline
\end{tabular}


Table 1.

List of SIRCs or Baitulmal Institutions based on Regions in Malaysia with the Enactment Adopted and the Corresponding Codes (Continued)

\begin{tabular}{|c|c|c|c|c|c|}
\hline No. & State & $\begin{array}{c}\text { Islamic State } \\
\text { Council }^{4}\end{array}$ & $\begin{array}{l}\text { Enactment adopted for } \\
\text { Waqf Management }{ }^{5}\end{array}$ & Region & $\begin{array}{l}\text { Region } \\
\text { Codes }\end{array}$ \\
\hline 6. & Terengganu & $\begin{array}{l}\text { Majlis Agama } \\
\text { Islam dan } \\
\text { Adat Melayu } \\
\text { Terengganu } \\
\text { (MAIDAM) }\end{array}$ & $\begin{array}{l}\text { Administration of } \\
\text { Islamic Religious Affairs } \\
\text { (Terengganu) Enactment } \\
\text { 1422H/2001M (En. 2/2001) }\end{array}$ & & \\
\hline 7. & Pahang & $\begin{array}{l}\text { Majlis Ugama } \\
\text { Islam dan } \\
\text { Adat Resam } \\
\text { Melayu } \\
\text { Pahang }\end{array}$ & $\begin{array}{l}\text { Administration of Islamic } \\
\text { Law Enactment } 1991 \\
\text { (En.3/1991) }\end{array}$ & & \\
\hline 8. & Selangor & $\begin{array}{l}\text { Majlis Agama } \\
\text { Islam Selangor } \\
\text { (MAIS) }\end{array}$ & $\begin{array}{l}\text { Wakaf (State of Selangor) } \\
\text { Enactment } 1999 \text { (En. 7/1999) }\end{array}$ & Central & C \\
\hline 9. & Kuala Lumpur & $\begin{array}{l}\text { Majlis Agama } \\
\text { Islam Wilayah } \\
\text { Persekutuan } \\
\text { (MAIWP) }\end{array}$ & $\begin{array}{l}\text { Administration of Islamic } \\
\text { Law (Federal Territories) Act } \\
1993 \text { (Act 505) }\end{array}$ & & \\
\hline 10. & Johor & $\begin{array}{l}\text { Majlis Agama } \\
\text { Islam Johor } \\
\text { (MAIJ) }\end{array}$ & $\begin{array}{l}\text { Administration of the } \\
\text { Religion of Islam (State of } \\
\text { Johor) Enactment } 2003 \text { (En. } \\
\text { 16/2003) }\end{array}$ & South & $\mathrm{D}$ \\
\hline 11. & Melaka & $\begin{array}{l}\text { Majlis Agama } \\
\text { Islam Melaka } \\
\text { (MAIM) }\end{array}$ & $\begin{array}{l}\text { Wakaf (State of Malacca) } \\
\text { Enactment } 2005 \text { (En. 5) }\end{array}$ & & \\
\hline 12. & $\begin{array}{l}\text { Negeri } \\
\text { Sembilan }\end{array}$ & $\begin{array}{l}\text { Majlis Agama } \\
\text { Islam Negeri } \\
\text { Sembilan } \\
\text { (MAINS) }\end{array}$ & $\begin{array}{l}\text { Wakaf (Negeri Sembilan) } \\
\text { Enactment } 2005 \text { (En. 2) }\end{array}$ & & \\
\hline 13. & Sabah & $\begin{array}{l}\text { Jabatan Hal } \\
\text { Ehwal Agama } \\
\text { Islam Negeri } \\
\text { Sabah }\end{array}$ & $\begin{array}{l}\text { Majlis Ugama Islam Negeri } \\
\text { Sabah Enactment } 2004 \text { (EN. } \\
\text { 5/2004) }\end{array}$ & $\begin{array}{c}\text { East of } \\
\text { Malaysia }\end{array}$ & E \\
\hline 14. & Sarawak & $\begin{array}{l}\text { Jabatan } \\
\text { Agama Islam } \\
\text { Sarawak }\end{array}$ & $\begin{array}{l}\text { Majlis Islam Sarawak } \\
\text { Ordinance } 2001 \text { (Chapter 41) }\end{array}$ & & \\
\hline
\end{tabular}

4. http://www.jawhar.gov.my/en/majlis-agama-islam-negeri/

5. http://www.esyariah.gov.my 


\subsection{Current Practices: Human Resource}

Based on semi-structured interview conducted to the seven selected Waqf institutions in Malaysia particularly regarding the current practice of human resource management, two matters are discussed; manpower and training given to the employees.

The number of work force in Region A particularly for cash Waqf management on average is approximately four personnel. In Region A, the training is provided to expose the staff on Waqf matters. One of the respondents stated that:

"...since the institution is under supervision of JAKIM (Department of Islamic

Development Malaysia) and JAWHAR, any training or education is based on JAKIM and JAWHAR..." (Representative of Region A, A1)

For Region B, the current number of work force, particularly for cash Waqf management, on average is approximately eight personnel. The training provided differs among the representatives. One representative stated that the training provided is to expose staff on the e-Waqf system while the other stated none.

For Region C, the average number of work force particularly for cash Waqf management currently is approximately 19 staff. This region also held training that enhance the employee's self-confidence and engaged external courses to enhance the employee's knowledge on cash Waqf management.

"...Marketing course to enhance the confidence of the staff to face the target group.

External courses to enhance the knowledge regarding cash Waqf management..."

(Representative of Region C, C1)

For Region D, the average number of manpower particularly for the cash Waqf management currently is approximately seven personnel. As for training, the current practice by this region is through informal training.

"...The current practice is the informal training where the new staffs are trained by previous employee or through the visits of other Waqfinstitutions..." (Representative of Region D, D1)

Based on previous study by Sayin, Ali and Suyurno (2006) on eight selected Waqf institutions in Malaysia, the average number of personnel managing Waqf for Region A is five, Region B is seven and four personnel for Regions C and D. For Region E, no personnel is stated for Waqf management (Sayin, Ali, \& Suyurno, 2006).

An exploratory study through the exploration of the Waqf institutions' official website and portals has also been done to compare the results of the exploration method and interview method. The summary of the work force of each Waqf institutions are as shown in Table 2. 
Table 2.

Manpower Level of Waqf Institution in Malaysia

\begin{tabular}{|c|c|c|c|}
\hline State & $\begin{array}{l}\text { Number of } \\
\text { Division / } \\
\text { Department }\end{array}$ & $\begin{array}{l}\text { Waqf Department / Unit } \\
\text { (Number of Personnel) }\end{array}$ & $\begin{array}{c}\text { Region (Average Number } \\
\text { of Personnel Managing } \\
\text { Waqf) }\end{array}$ \\
\hline Perlis & 6 units & $\begin{array}{l}\text { Waqf and General Resources } \\
\text { Unit, Baitulmal Services (4) }\end{array}$ & Region A (8) \\
\hline Kedah & - & $-(-)$ & \\
\hline Penang & 6 departments & Waqf Department (13) & \\
\hline \multirow[t]{2}{*}{ Perak } & $\begin{array}{l}4 \text { divisions with } 13 \\
\text { units }\end{array}$ & $\begin{array}{l}\text { Waqf Section, Investment } \\
\text { Unit (6) }\end{array}$ & \\
\hline & & $\begin{array}{l}\text { Cash Waqf \& Land Sale, } \\
\text { Operation \& Marketing Unit } \\
\text { (3) }\end{array}$ & \\
\hline Kelantan & $\begin{array}{l}3 \text { divisions with } 20 \\
\text { units }\end{array}$ & $\begin{array}{l}\text { No specific division or unit } \\
\text { for } \operatorname{Waqf}(-)\end{array}$ & Region B (7) \\
\hline Terengganu & $\begin{array}{l}8 \text { divisions and } 8 \\
\text { departments with } \\
9 \text { units }\end{array}$ & $\begin{array}{l}\text { Waqf and General Resources } \\
\text { Unit, Baitulmal Department } \\
(-)\end{array}$ & \\
\hline Pahang & $\begin{array}{l}2 \text { departments with } \\
11 \text { units }\end{array}$ & $\begin{array}{l}\text { Waqf Unit, Baitumal } \\
\text { Department (7) }\end{array}$ & \\
\hline $\begin{array}{l}\text { Selangor (Selangor } \\
\text { Waqf Corporation) }\end{array}$ & $\begin{array}{l}4 \text { divisions with } 10 \\
\text { units }\end{array}$ & Total: 38 & Region C (38) \\
\hline $\begin{array}{l}\text { Wilayah } \\
\text { Persekutuan }\end{array}$ & $\begin{array}{l}8 \text { divisions and } 2 \\
\text { units }\end{array}$ & $\begin{array}{l}\text { No specific division or unit } \\
\text { for } \operatorname{Waqf}(-)\end{array}$ & \\
\hline Johor & $\begin{array}{l}4 \text { divisions with } 12 \\
\text { units }\end{array}$ & $\begin{array}{l}\text { Waqf Section, Waqf \& } \\
\text { Baitulmal Division (-) }\end{array}$ & Region D (15) \\
\hline Melaka & 6 divisions & $\begin{array}{l}\text { Waqf \& General Resources } \\
\text { (23) }\end{array}$ & \\
\hline $\begin{array}{l}\text { Negeri Sembilan } \\
\text { (Negeri Sembilan } \\
\text { Waqf Corporation) }\end{array}$ & - & Total: 7 & \\
\hline Sabah & 10 divisions & $\begin{array}{l}\text { No specific division or unit } \\
\text { for } \operatorname{Waqf}(-)\end{array}$ & Region E (0) \\
\hline Sarawak & $\begin{array}{l}10 \text { divisions with } \\
6 \text { units }\end{array}$ & $\begin{array}{l}\text { No specific division or unit } \\
\text { for } \operatorname{Waqf}(-)\end{array}$ & \\
\hline
\end{tabular}

\subsection{Current Practices: Documentation}

In terms of documents, three areas that being discussed consist of collection, investment and distribution of cash Waqf.

In Region A, the documentation of cash Waqf collection is mostly done by using a specific software system. Only one of the Waqf institutions is still documenting cash Waqf collection manually by using Microsoft Excel. On the other hand, there is no documentation on the investment of cash Waqf because cash Waqf investment 
is not implemented yet in this region. In spite of that, the documentation practices for the distribution of cash Waqf varies among the Waqf institutions as reported by their representative in Region A.

In Region B, the current practice of documenting cash Waqf collection is by using specific software systems, User Business System (UBS), for accounting and e-Waqf. However, there is no documentation for both cash Waqf investment and cash Waqf distribution.

In Region C, the current practice of the documentation for all collection, investment and distribution of cash Waqf is done by using a specific software system called SWS and SAGA. In contrast, Region D has no documentation for both investment and distribution of cash Waqf. The documentation in Region D is only available for the collection of cash Waqf where it is documented manually by using Microsoft Excel. The overall information on documentation practices of the selected Waqf institutions are as shown in Table 3 below.

Table 3.

Current Practice of Documentation by Selected Waqf Institutions based on Region in Malaysia

\begin{tabular}{|c|c|c|c|c|}
\hline Region & $\begin{array}{l}\text { Representative } \\
\text { Code }\end{array}$ & Collection & Investment & Distribution \\
\hline \multirow[t]{3}{*}{ A } & A1 & Idwal System & - & Idwal System \\
\hline & A2 & Sistem Hasil and UBS & - & - \\
\hline & A3 & $\begin{array}{l}\text { Manually record using Microsoft } \\
\text { Excel }\end{array}$ & - & $\begin{array}{l}\text { Manually } \\
\text { record using } \\
\text { Microsoft } \\
\text { Excel }\end{array}$ \\
\hline \multirow[t]{2}{*}{ B } & B1 & Yes & - & No \\
\hline & B2 & $\begin{array}{l}\text { UBS for accounting and e-Waqf } \\
\text { system }\end{array}$ & - & - \\
\hline $\mathrm{C}$ & $\mathrm{C} 1$ & SWS system and SAGA & SAGA & SAGA \\
\hline $\mathrm{D}$ & D1 & $\begin{array}{l}\text { Manually record using cash } \\
\text { book and Microsoft Excel }\end{array}$ & - & - \\
\hline
\end{tabular}

\subsection{Current Practices: Reporting}

This research captured two aspects of reporting which are revenue and expenditure disclosure as well as the activity reports. For Region A, the current practice of reporting cash Waqf in their annual statement varies. Most of the representatives of the Waqf institutions have stated that they distinctively disclose all revenue and expenditure of cash Waqf fund. However, most of the Waqf institutions do not have written explanation or report on cash Waqf fund allocation for activities held in the reporting year.

For Region B, the current practice of reporting cash Waqf in their annual statement also varies. One of the representatives of the Waqf institutions have statements that distinctively disclose all revenue and expenditure of cash Waqf 
funds and have written explanation on cash Waqf fund allocation for activities held in the reporting year. Meanwhile the other Waqf institution does not disclose the information regarding their reporting at all.

For Region C, the representative of the Waqf institutions has statements that disclose all revenue and expenditure of the cash Waqf fund. Nevertheless, the Waqf institution does not have written explanation on cash Waqf fund allocation for activities held in the reporting year.

For Region D, the representative neither has statements that disclose all revenue and expenditure of cash Waqf fund nor written explanation on cash Waqf fund allocation for activities held in the reporting year.

\subsection{Challenges in Managing Cash Waqf}

\subsubsection{Human Resources}

There are few challenges faced by the Waqf institutions in managing human resource pertaining cash Waqf management according to regions in Malaysia. This research also identified the current staff's performance to clarify the challenges faced by the representatives of Waqf institutions.

In Region A, most of the representatives faced a challenge in operation aspect and one of the representatives stated that it is due to previous staff's management practices. However, the representative also stated that the current staff performance is good and has improved over time. Below is the response of one representative in Region A.

"...The current staffs unable to trace back the old records from previous staff or officers as the Waqf operation previously has been done verbally without writing evidences... No problem with the current staff performance but lacking in manpower reduces the overall job performance." (Representative of Region A, A1)

In contrast, Region B commented that they have no difficulty in managing cash Waqf. In Region C, they faced the problem of staff time management at the early stage. However, performance of the staff is satisfactory and improved over time.

"...It is a bit difficult at the early stage but it is just a technical difficulties (i.e. delay in weekly collection report). However, the current situation is much better with more efficient time management..." (Representative of Region C, C1)

Meanwhile in Region D, they faced a problem in managing cash Waqf because the staff recruited for the particular duty has no background in financial management. Thus, the cash Waqf documentation is recorded but not in proper financial format.

"...No difficulties in understanding the concept of cash Waqf. However, to teach the cash Waqf documentation or the financial management (i.e. the record keeping of cash book and ledger) is a bit challenging as the staff recruited under cash Waqf has no background study of financial management..." (Representative of Region D, D1)

\subsubsection{Documentation}

For documentation, most of the representatives in Region A have no difficulties in documenting the collection, investment and distribution of cash Waqf. In spite of this, it is worth to mention one of the responses regarding the difficulty in documentation of cash Waqf collection as stated below: 
"...late submission of collection form from each district..." (Representative of Region A, A3)

In Region B, the comments vary. One of the representatives stated that there are no problems while the other representative stated that they faced difficulty in cash Waqf collection because they practiced manual documentation. Apart from that, there are no problems in documentation of investment and distribution in Region B.

In Region C, their response is either no problem or difficulty in documenting all the collection, investment and distribution of cash Waqf. On the contrary, for Region D, they faced challenges in documenting the collection of cash Waqf as it is done manually and some of the cash-endowed sources cannot be traced. As for the documentation of investment and distribution of cash Waqf, they stated that there are no issues. The response is as stated below:

"...manually record using cash book and Microsoft Excel...the source of the cash endowed cannot be traced..." (Representative of Region D, D1)

\subsubsection{Reporting}

In reporting aspect, the current research indirectly figured the challenges faced by the representatives of the Waqf institution in each region based on their answers in current practices of reporting. To be brief, regions that has non-disclosure on cash Waqf revenue and expenditure or no cash Waqf activity report is regarded as having issues in reporting.

The research found that Region D is currently having issues in reporting aspect. However, the current research could not identify the specific issue in the reporting aspect since the research only focus on the availability of cash Waqf revenue, expenditure as well as its activity report.

\subsection{Discussions}

It is observed that some of the Waqf institutions in Malaysia, specifically in Region C and Region D (Kuala Lumpur, Johor, Melaka, and Negeri Sembilan), have specific enactments pertaining to Waqf. The presence of cash Waqf law reflects the strong will of the regulators towards cash Waqf application because it acts as a tool of social engineering in influencing and transforming the public to the desired changes (Hilmi, 2012a). In view of that, Waqf enactment is important to change the public's understanding on Waqf participation by means of cash Waqf. Thus, the existence of Waqf enactment in Region C and Region D, which also rule the cash Waqf implementation, portrays the attentiveness of these Waqf institutions that are currently empowered by the state to act as the sole trustee in implementation and promotion of cash Waqf to the society.

Meanwhile, with regards to the financial sources of the respective Waqf institutions, it is found that the majority of the Waqf institutions has initiated to collect Waqf funds using various ways and medium and become independent to sustain in future. It is believed that these institutions have their own wisdom to promote the Waqf concept to the society. Being dependent on limited financial sources from the federal government is one of the weaknesses in Waqf management 
(Siraj, 2012). Thus, when these Waqf institutions have the ability to innovate new ways of promoting cash Waqf and proactively implement it by using current technology such as e-wakaf, bank draft and Wakaf online, these will attract the private sector to take part in the revitalization of Waqf.

In terms of the implementation period of cash Waqf by the institutions, it is noted that Region B (Kelantan, Terengganu, and Pahang) has implemented the cash Waqf concept for more than 10 years. A previous study on organizations found that there is a positive relationship between experience and organization performance (Luo \& Peng, 1999). In this regards, the current research uses the same perspective towards the experience of cash Waqf implementation by Waqf institutions against the performance of cash Waqf revitalization. Waqf institutions with longer period or experience in cash Waqf implementation reflect their supportiveness towards promotion of cash Waqf and shall portray better performance than other regions.

\subsubsection{Cash Waqf Management Practices}

Interviews with representatives of the respective Waqf institutions show that there are differences in number of officers or persons in charge for cash Waqf. Overall, Region C (Selangor and Kuala Lumpur) has the highest average number of work force size who manages the collection, investment and distribution of cash Waqf. Meanwhile, Region A (Perlis, Kedah, Penang, and Perak) has the lowest average of manpower size who manages mainly the collection of cash Waqf. Thus, this shows that Region $C$ that managed more activities pertaining cash Waqf would have bigger work force size than the other region. This difference happens due to the institutions strategic planning for cash Waqf collection, investment, and distribution as shown in Table 4. It is observed that the institutions that planned more activities pertaining to cash Waqf will have more work forces to realize the plan. Based on previous literature, number of employees or work force in an organization would affect positively with organizational effectiveness in doing their business activities (Connell, 2001). Thus, the bigger number of work force of Waqf institutions in Region C is reflected by their strategic planning for cash Waqf activities and this indicates that there are bright futures of cash Waqf empowerment in this region, particularly the state of Selangor and Kuala Lumpur.

Table 4.

Availability of Strategic Planning in cash Waqf activities by Selected Waqf Institutions based on Region in Malaysia

\begin{tabular}{lccccc}
\hline \multirow{2}{*}{ Activities } & \multicolumn{5}{c}{ Region } \\
\cline { 2 - 6 } & A & B & C & D & E \\
\hline Collection & Yes & Yes & Yes & Yes & Not Applicable \\
Investment & Varies & Varies & Yes & No & Not Applicable \\
Distribution & Varies & Yes & Yes & No & Not Applicable \\
\hline
\end{tabular}


In addition, for human resources management, this research also investigates the training received by the Waqf employees in managing cash Waqf. It is found that the training provided to the personnel for each region varies depending on the activities of the institutions. However, it is worthy to note that the management of JAWHAR supervises the training of the personnel in each region. In fact, JAWHAR is very keen in human resource management in order to strengthen the Waqf institutions in each state. This research however does not investigate deep into the effectiveness of the existing training that the Waqf personnel are currently undergoing. In this context, the current research only emphasized the manpower size in determining the effectiveness of Waqf institution handling cash Waqf management.

\subsubsection{Documentation}

Another aspect of cash Waqf management is documentation of cash Waqf. It is discussed based on three aspects which are collection, investment and distribution of cash Waqf. According to Gaudiosit (1988), the crucial responsibilities of the Waqf institutions, as described by the Muslim jurists, were the preservation of the Waqf, collection of Waqf income, distribution of the income generated to the appropriate beneficiaries, management of personnel, and resolution of disputes on Waqf. The documentation of these activities is either done by using system software or manual. From observation, the technology advancement in Region C, specifically the Selangor state, is better than the other regions as this region uses a software system in documenting all cash Waqf activities. These include the collection, investment and distribution of the cash Waqf fund. On the other hand, Region D specifically, the Negeri Sembilan state, has yet to utilize current technologies in their Waqf activities. This is possibly because of Waqf institution in Negeri Sembilan state, which is Perbadanan Wakaf Negeri Sembilan, has just taken over the Waqf operation from Majlis Agama Islam Negeri Sembilan in January 2013.

\subsubsection{Reporting}

The last aspect of cash Waqf management that is concerned in this research is in terms of reporting. In this context, it is found that most of the Waqf institutions disclose their activities and other details related to cash Waqf in their annual report. However, only three of them have disclosed and shared their annual reports through their official website portal. These institutions are Majlis Agama Islam Wilayah Persekutuan (MAIWP), Majlis Agama Islam Selangor (MAIS) and Majlis Agama Islam Perak (MAIPk). In this regard, all Waqf institutions in Malaysia should disclose and share the reporting of cash Waqf financial figures to the public as it discharges the accountability as a trustee and at the same time enhance the interests of the public to participate in cash Waqf contribution.

\subsubsection{Current Challenges of Cash Waqf Implementation}

Based on the interviews, this research found three main concerns reported by the representatives of Waqf institutions in Malaysia related to human resource 
management. First is the shortage of talent in Waqf. It is reported that it is difficult to search for young and experienced expert in Waqf and even fresh graduate that specialize in Waqf or have Shari'ah background to work with Waqf institutions. Similarly, findings from previous research indicated that the obvious challenge to manage cash Waqf is developing a qualified expert pool in Waqf (Siraj, 2012). Second, there are also problems with the performance of the Waqf personnel in managing cash Waqf. In this context, it is noticed that there is no competition among the personnel to upgrade their performance. Everybody is in his or her comfort zone and there are no pushing factors for him or her to enhance their works for a better performance in the future. Finally, the constraints faced by the institutions are also concerning the academic background of their personnel. For the finance-related activities, personnel that graduated with finance background are highly required to manage financial matters. However, in some of the Waqf institutions, the personnel consist of those who graduated from various educational backgrounds where graduates with Shari'ah background become the priority to be selected. It is good to acquire staff from various educational backgrounds but effective training must be properly conducted to enhance their knowledge and skills. As stated by Iman and Mohamad (2014), employees in Waqf institutions are not properly trained for the purpose of Waqf including cash Waqf management. Currently, the training organized to the staff is not enough and is ineffective to upgrade their skills in managing Waqf asset, particularly in managing cash Waqf. Thus, more effort should be done to attract more talents to specialize in Waqf and more training that is effective should be conducted to the existing personnel. Hence, by addressing the human resource constraints, this has some effect towards cash Waqf management as a whole.

In terms of documentation, the current research found that it is a major challenge for the existing Waqf institutions to effectively maintain their current documentation without utilizing latest technology advancement such as special software or program. Documentation, when manually done, limits the effectiveness of the current record keeping for cash Waqf activities since the contribution is made by means of money in thousands of Ringgits. Previous research also stated that in order to enhance administration performance as well as expediting the process, Waqf institutions must have the latest technology for their database management (Sanusi \& Shafiai, 2015). The current technology used by Waqf institutions explain the reason of the non-availability of proper documentation of cash Waqf investments, especially the investment activity of cash Waqf.

The reporting aspect would be challenging as no proper documentation are maintained. As a matter of fact, only a few Waqf institutions managed to publish their annual reports in their official website. Still, it is not properly updated to the latest year. Furthermore, the current reports on Waqf asset or cash Waqf also became less reliable as the institutions countered several issues pertaining to their Waqf accounting practices. This issue arose from the shortage of qualified and experienced personnel that specializes in accounts (accountant) and also lack of proper training by the Waqf institutions which lead to the delay in the preparation of reliable financial statement (JAWHAR, 2009). Furthermore, the lack of expertise in Waqf institutions to update the information on their official websites shall partly explain the limited utilization of their website for reporting (Siraj, 2012). 


\section{CONCLUSIONS AND RECOMMENDATIONS}

\subsection{Recommendation for Improvement}

\section{A. Human Resources Management}

For a non-profit organization, its performance shall be measured by the quality of the workforce input, which comprises of human capital, training and structures (Abraham, 2004). First, effective training courses should be conducted to the existing Waqf employees. It is recommended that the Waqf institutions conduct special trainings on organizational, leadership, financial as well as marketing management courses as these are the top learning goals for non-profit organization (Garvey, 2009). These training courses should be monitored in a timely basis according to the strategic planning of the institutions.

Second, the establishment of cash Waqf expert management committee is required to ensure the existing employees are competent and up-to-date with any information related to Waqf. This internal committee may collaborate with the experts from the academician in order to assist them with related information or sharing related materials to further enhance Waqf staff effectiveness. This could be done through a Memorandum of Understanding (MoU) or jointly research collaboration between academic and Waqf institutions. Furthermore, Waqf institutions also need to increase the size of the human capital in accordance with the workload for the full realization of the cash Waqf concept. This is crucial because the revival of cash Waqf concept cannot be fully executed without enough experts in financial management, strategic management, and Islamic rules.

Moreover, the implementation of KPI (Key Performance Index) for each employee, as practiced in Region C, to cater the problem of its employees' attitude, specifically with time management, is highly admirable. In line with that, the top managements are responsible to generate, convey the strategic management planning, especially in cash Waqf projects, in order to boost the motivation of the employee towards cash Waqf implementation.

\section{B. Documentation}

Based on the previous findings and discussion, it is clearly shown that Waqf institutions in Malaysia need process enhancements of the current practices of documentation. These consist of the process of documenting the collection, investment and distribution of cash Waqf. It is essential to systemize the operations since the involvement of contribution of cash Waqf collection will increase as public awareness increases. Currently, the documentation practice is focused on documenting the declaration of Waqf as well as other related documents such as forms (Iman \& Mohammad, 2014).

However, moving forward, the Waqf institution is recommended to prepare outstanding documentation as well as working papers of the initiatives and strategic plans in cash Waqf projects. This is critical in order to attract and engage the private sectors. The Waqf institutions in Malaysia shall take the example of Singapore and Saudi Arabia in utilizing cash Waqf by introducing Sukuk Waqf to raise millions of capital for their Waqf development (Abdul-Karim, 2010; Jalil \& Ramli, 2008; Kholid et al., n.d.). 


\section{Reporting}

The existing Waqf institutions need to improve in terms of documentation to produce transparent and reliable reports to the public. This is important in not only enhancing awareness of cash Waqf contribution, but also instilling confidence among the contributors towards the Waqf institutions in terms of financial management, as the official annual reports would portray the trustworthiness of the management. Reliable reports of the current initiatives in ibtidal projects are also important in order to engage the private sectors.

Unlike in the private sector, profit maximization is not the main objective of Waqf. One of the methods that can fulfill the perpetuity principle in Waqf is to uphold the perpetuity element in cash Waqf, profitable projects and ventures. Thus, Waqf institutions shall prepare a complete and captivating report on their projects that will motivate private institutions to join a venture.

\subsection{Limitation and Suggestions for Future Researches}

This research only emphasizes the internal constraints in selected Waqf institutions by regions in Malaysia. It only covers three aspects, which are human resource management, documentation management and reporting aspect. Thus, it limits the findings and conclusions of this research. This is inevitable since the concept of cash Waqf is still in its infancy stage in Malaysia.

As this research focused only on selected Waqf institutions and three aspects, the findings could not precisely portray the overall cash Waqf management practices in Malaysia. It is encouraged for future researchers to cover all aspects of Waqf management practices. In addition, the future research should include all aspects of Waqf management, for example the internal as well as the external aspects covering all Waqf institutions in Malaysia. It can also cover the private Waqf institutions in order to yield well-defined findings.

Future research should also consider an empirical study as it could help to measure the performance and efficiency of cash Waqf management by Waqf institutions in Malaysia. The impact of cash Waqf investments towards the Waqf development could also be tested. Another useful topic for future research would be the significant improvement in cash Waqf management practices throughout the period of study, which pinpoints other challenges faced by Waqf institutions in the revitalization of cash Waqf concept.

\section{REFERENCES}

Abdul-Karim, S. (2010). Contemporary Shari'ah Structuring for the Development and Management of Waqf Assets in Singapore (Doctoral dissertation, Durham University).

Abraham, A. (2004). A Model of Financial Performance Analysis Adapted for Nonprofit Organisations. In AFAANZ 2004 Annual Conference. Alice Springs.

Al Arif, M. N. R. (2010). Pemberdayaan Masyarakat Berbasis Wakaf Uang. Jurnal Asy-Syir'ah, Fakulti Syariah UIN Sunan Kalijaga Yogyakarta, 44(2), 813-828.

Amuda, Y. J., Embi, A. C., \& Babatunde, O. H. (2014). An Agricultural Approach to the Commercialization of Cash Waqf between Malaysia and Nigeria. Journal of Advanced Management Science, 2(4), 344-348. 
Amuda, Y. J., \& Embi, N. A. C. (2013). Alleviation of Poverty among OIC Countries through Sadaqat, Cash Waqf and Public Funding. International Journal of Trade, Economics and Finance, 4(6), 403-408.

Burns, A. C., \& Bush, R. F. (2010). Understanding Research Design. In Marketing Research (6 ${ }^{\text {th }}$ ed., pp. 140-168). New Jersey: PEARSON Education.

Chowdhury, M. S., Ghazali, M. F., \& Ibrahim, M. F. (2011). Economics of Cash Waqf Management in Malaysia: A Proposed Cash Waqf Model for Practitioners and Future Researchers. African Journal of Business Management, 5(30), 12155-12163.

Connell, J. (2001). Influence of Firm Size on Organizational Culture and Employee Morale. Journal of Management Research, 1(4), 220.

Department of Awqaf Zakat \& Hajj [JAWHAR]. (2009). Manual Pengurusan Wakaf Tunai. Putrajaya: JAWHAR.

Eriksson, P., \& Kovalainen, A. (2008). Qualitative Research Materials. In Qualitative Methods in Business Research (1 ${ }^{\text {st }}$ ed., pp. 77-94). London: SAGE Publications Ltd.

Fanani, M. (2011). Pengelolaan Wakaf tunai. Walisongo, 19(1), 179-196.

Garvey,D. (2009). NonprofitSector:Workforce Education Needs and Opportunities. Continuing Higher Education Review, 73, 114-124.

Gaudiosit, M. M. (1988). The Influence of the Islamic Law of Waqf on the Development of the Trust in Engand: The Case of Merton College. University of Pennsylvania Law Review, 136(4), 1231-1261.

Hanefah, M. M., Jalil, A., Ramli, A. M., Sabri, H., Nawai, N., \& Shahwan, S. (2009). Financing the Development of Waqf Property: The Experience of Malaysia and Singapore. In International Conference on Waqf Laws and Management: Reality and Prospects. Gombak.

Hayani, F. (2007). Wakaf Tunai Dalam Perspektif Ulama Fiqih (Studi Analisis Pendapat Ulama Hanafiyah dan Safi'iyah) (Doctoral dissertation, Universitas Islam Negeri Syarif Hidayatullah, Jakarta).

Hilmi, H. (2012a). Dinamika Pengelolaan Wakaf Uang: Studi sosio-legal perilaku pengelolaan wakaf uang pasca pemberlakuan UU No. 41 tahun 2004 tentang wakaf. Jurnal Wacana Hukum Islam Dan Kemanusiaan, 12(2), 123-143.

Hilmi, H. (2012b). Wakaf Uang Antara Fleksibilitas Berderma dan Sistim Ribawi. Jurnal Pengembangan Masyarakat, 5(1), 40-54.

Hosseini, S. M. S., Salari, T. E., \& Abadi, S. M. N. Z. (2014). Study of Cash Waqf and Its Impact on Poverty (Case Study of Iran). Atlantic Review of Economics, 2.

Htay, S. N. N., Mohamed, M. O., \& Osman, A. F. (2012). Determinants of Cash Waqf Giving in Malaysia: Survey of Selected Works. In Workshop Antarbangsa Pembangunan Berteraskan Islam V (WAPI-5). Medan, Indonesia.

Ibrahim, D., \& Ibrahim, H. (2013). Revival of Waqf Properties in Malaysia. In The 5th Islamic Economics System Conference (iECONS 2013). Kuala Lumpur.

Ibrahim, H., Amir, A., \& Masron, T. A. (2013a). Cash Waqf: An Innovative Instrument for Economic Development. International Review of Social Sciences and Humanities, 6(1), 1-7.

Ibrahim, H., Nor, E., \& Muhammad, J. (2013b). Cash Waqf and Its Development in the Northern Region of Malaysia. In $4^{\text {th }}$ International Conference on Business and Economic Research (4th ICBER 2013) Proceeding. Bandung.

Iman, A. H. M., \& Mohammad, M. T. S. (2014). Waqf Property: Concept, Management, Development, and Financing ( $1^{\text {st }}$ ed.). Johor Bahru: PENERBIT UTM PRESS. 
Ismail, C. Z., Muda, S., \& Hanafiah, N. J. A. (2014). Challenges and Prospects of Cash Waqf Development in Malaysia. Journal of Basic and Applied Scientific Research, 4(2), 340-348.

Jalil, A., \& Ramli, A. M. (2008). Waqf Instruments for Construction Contract: An Analysis of Structure. The Journal of Muamalat and Islamic Finance Research, 5(1), 183-197.

Kader, S. Z. S. A. (2015). The Legal Framework of Waqf in Malaysia. Retrieved from http://ssrn.com/abstract=2547440 2.

Kahf, M. (1999). Financing the Development of Awqaf Property. American Journal of Islamic Social Sciences, 16(4), 39-68.

Khademolhoseini, M. (2008). Cash Waqf a New Financial Instrument for Financing Issues: An Analysis of Structure and Islamic Justification of Its Commercialization. Imam Sadiq University.

Kholid, M., Sukmana, R., \& Hassan, K. A. K. (n.d.). Waqf through Sukuk Al-Intifa'a: A Proposed Generic Model. Retrieved from http://www.mbri.ac.ir/userfiles/ file/Islamic Banking

Luo, Y., \& Peng, M. W. (1999). Learning to Compete in a Transition Economy: Experience, Environment, and Performance. Journal of International Business Studies, 30(2), 269-295.

Manat, A. B. (2007). Isu-isu Semasa Berhubung Pembangunan Tanah Wakaf. Jurnal Pengurusan JWZH, 1(1), 53-71.

Marzuki, M. U., Shahimi, S., Ismail, A. G., \& Embong, Z. (2012). Tackling Poverty: A Look at Cash Waqf. In Prosiding PERKEM VII. Perak.

Masruki, R., \& Shafii, Z. (2013). The Development of Waqf Accounting in Enhancing Accountability. Middle-East Journal of Scientific Research (Research in Contemporary Islamic Finance and Wealth Management), 1-6.

Masyita, D., \& Febrian, E. (2004). The Role of BRI in the Indonesian Cash Waqf House's System. In BRI International Seminar on Developing Microbanking: Creating Opportunities for the Poor through Innovation. Bali.

Masyita, D., Tasrif, M., \& Telaga, A. S. (2005). A Dynamic Model for Cash Waqf Management as One of the Alternative Instruments for the Poverty Alleviation in Indonesia. In The $23^{\text {rd }}$ International Conference of the System Dynamics Society Massachussets Institute of Technology (MIT). Boston.

Medias, F. (2010). Wakaf Produktif Dalam Perspektif Ekonomi Islam. Jurnal Ekonomi Islam, 4(1), 69-84.

Mohsin, M. I. A. (2013). Financing Through Cash Waqf: A Revitalization to Finance Different Needs. International Journal of Islamic and Middle Eastern Finance and Management, 6(4), 304-321.

Nurrachmi, R. (2012). The Implication of Cash Waqf in the Society. Munich Personal RePEc Archive, 150-155. Retrieved from http://mpra.ub.uni-muenchen. de/44605/.

Pitchay, A. A., Mydin, A. K. M., \& Saleem, M. Y. (2014). Priority of Waqf Development among Malaysian Cash Waqf Donors: An AHP Approach. Journal of Islamic Finance, 3(1), 13-22.

Rozalinda. (2012). Manajemen Risiko Investasi Wakaf Uang. Islamica:Jurnal Studi Keislaman, 6(2), 300-315. 
Saad, N. M., \& Anuar, A. (2010). Cash Waqf and Islamic Microfinance: Untapped Economic Opportunities. Islam and Civilisational Renewal, 1(2), 337-354.

Saifuddin, F., Kayadibi, S., Polat, R., Fidan, Y., \& Kayadibi, O. (2014). The Role of Cash Waqf in Poverty Alleviation: Case of Malaysia. In Kuala Lumpur International Business, Economics and Law Conference 4 (KLIBEL4). Kuala Lumpur.

Sanusi, S., \& Shafiai, M. H. M. (2015). The Management of Cash Waqf : Toward Socio-Economic Development of Muslims in Malaysia. Jurnal Pengurusan, 43(2015), 3-12.

Sayin, B., Ali, A. H., \& Suyurno, S. S. (2006). Pengenalan kepada Konsep Wakaf dalam Islam. Kuala Lumpur: Pusat Penerbitan Universiti (UPENA), UiTM.

Shahimi, S., Marzuki, M. U. M., \& Embong, Z. (2013). Potential of Cash Waqf for Poverty Alleviation in Malaysia: A System Dynamics Approach. Jurnal Ekonomi Malaysia, 47(2), 149-163.

Shakrani, M. S., Noor, M. S. Z., \& Ali, J. (2003). Tinjauan Isu-Isu Yang Membataskan Penggunaan Wakaf Dalam Pembangunan Ekonomi Ummah di Malaysia. Jurnal Syariah, 11(2), 73-98.

Siraj, S. A. (2012). An empirical investigation into the accounting, accountability and effectiveness of waqf management in the State Islamic Religious Councils (SIRCS) in Malaysia (Doctoral dissertation, Cardiff University).

Sudirman. (2004). Pegembangan Wakaf Tunai untuk Keadilan Sosial: Studi tentang Manajemen Wakaf Tunai di Tabung Wakaf Indonesia. Research Collections. Retrieved from http://ejournal.uin-malang.ac.id/index.php/research/article/ view/2085.

Tohirin, A., \& Hudayati, A. (2011). Cash Waqf Institution and Accounting Issues. In International Seminar \& Workshop on Islamic Accounting. Yogyakarta.

Toraman, C., Tuncsiper, B., \& Yilmaz, S. (2007). Cash Awqaf in the Ottomans as Philanthropic Foundations and Their Accounting Practices. In The $5^{\text {th }}$ Accounting History International Conference. Banff, Canada.

Yaacob, H., Petra, S., Sumardi, A., \& Nahar, H. S. (2012). Awqaf Accounting and Reporting for Accountability: A Case Study of Awqaf S. In The $19^{\text {th }}$ International Business Research Conference. Melbourne.

http://www.esyariah.gov.my

http://www.jawhar.gov.my 
This page is intentionally left blank 